\title{
Municipal Solid Waste Quantity, Composition and Current Management Practices in Gilgit City, Gilgit-Baltistan, Pakistan
}

\author{
Farasat Ali ${ }^{1, ~ *, ~}$ Yawar Abbas $^{2}$, Attarad Ali ${ }^{3}$, Qasim Khan ${ }^{4}$, Nawazish Ali ${ }^{5}$, Rizwan Karim ${ }^{6}$, \\ Jarrar Hussain ${ }^{7}$, Islamuddin ${ }^{8}$ \\ ${ }^{1}$ World Wide Fund (WWF)-Pakistan, NLI (Northern Light Infantry) Colony Jutial Gilgit, Pakistan \\ ${ }^{2}$ Department of Earth and Environmental Sciences, Bahria University, Islamabad, Pakistan \\ ${ }^{3}$ Department of Biotechnology, Quaid-i-Azam University, Islamabad, Pakistan \\ ${ }^{4}$ Department of Environmental Sciences, Quaid-i-Azam University, Islamabad, Pakistan \\ ${ }^{5}$ Department of Agriculture and Food Technology, Karakoram International University, Gilgit, Pakistan \\ ${ }^{6}$ Department of Forestry and Range Management, PMAS-Arid Agriculture University, Rawalpindi, Pakistan \\ ${ }^{7}$ Environmental Protection Agency Gilgit-Baltistan, Pakistan \\ ${ }^{8}$ Rescue 1122 Gilgit, Pakistan
}

Email address:

attarad.ali@kiu.edu.pk (Attarad Ali)

\section{To cite this article:}

Farasat Ali, Yawar Abbas, Attarad Ali, Qasim Khan, Nawazish Ali, Rizwan Karim, Jarrar Hussain, Islamuddin. Municipal Solid Waste Quantity, Composition and Current Management Practices in Gilgit City, Gilgit-Baltistan, Pakistan. International Journal of Environmental Monitoring and Analysis. Vol. 3, No. 5, 2015, pp. 282-287. doi: 10.11648/j.ijema.20150305.16

\begin{abstract}
Gilgit city with an area of around 10 sq. kilometers and an estimated population of about $65,845.6$ people is most rapidly growing urban settlement of the province. This city generates about 42.5 tonne of waste per day and Municipal Committee Gilgit (MCG) is the authority responsible to manage this waste. The present annual budget of Municipal committee is around Rs. 1,8900000 (USD 189, 000). Equipments and machineries available for waste collection and transportation include 4 tractor trolleys, 200 Dustbins (installed), Dumpsters 15, Beats 7, Mazda 1 and, 25 wheel barrows. Waste is picked up manually using handcarts, baskets and polythene bags. Irregular and uncontrolled sweeping, confined to commercial zones, together with refuse generated from the household and commercial areas i.e. indiscriminately thrown on the roadsides. Tractor trolleys are used to collect and transport waste out of the city. There is no proper disposal method for the generated waste and is dumped on land within the city along Gilgit River (Indus River) bank. Major sources of waste in Gilgit city include, Household waste $40 \%$, Commercial establishment (e.g. shops and hotels, offices) $60 \%$. This generated waste is comprised of organic waste (e.g. food waste) 70-80\% Inorganic waste (e.g. plastic, glass and metals) $20-30 \%$.
\end{abstract}

Keywords: Solid Waste Management (SWM), Municipal Committee Gilgit (MCG), Budget, Organic Waste, Disposal

\section{Introduction}

Material unwanted or discarded from residential, commercial, industrial, mining, and agricultural activities cause environmental problems" (Dara, S.S., 1997). The solid waste if remained unattended lead to various environmental nuisances including, aesthetic degradation, breeding ground for vermin, production of offensive odours, methane release into the environment and resource waste etc. (International Resource Group, 2009). Municipal solid waste (MSW) or often termed trash or garbage includes solid or semi-solid material from domestic, commercial or institutional establishment that is no longer considered of any value to retain (Liu, C., and $\mathrm{Wu}, \mathrm{X}$. 2011). MSW is comprised of durable and non-durable goods, container and packaging, yard waste, food leftovers, and miscellaneous inorganic wastes, while waste from sources like demolition activities, sewage treatment industrial processes, and hazardous waste from hospitals is not included (Bureau of Waste Prevention, Reuse and Recycling, 2000).

Industrialization and its subsequent societal implications include production of unwanted materials no longer wanted by its producer. The most ubiquitous form of such waste is 
solid waste (Daskalopoulos, E., Badr, O., Propert, D. S.1998). The voluminous production of solid waste requires removal and disposal to avoid associated issues (Bai, R., \& Sutanto, M. 2002). Solid waste produced from human activities from individual to household, commercial to industry level is of various types viz. Compostable, recyclable, combustible, residual, and hazardous (Ejaro, S. P., \& Jiya, S. N. 2013). Proportion of these types of waste in overall waste stream is a function of lifestyle of the community, season, culture, religious customs, economic activities and conditions, affluence level in the locality under consideration (Guangyu, Y. 2014 and Amber I. et al., 2012). The amount of solid waste generated by humans is far greater than the capacity of the environment to incorporate it into ecosystem or render it harmless for the life. This has further exacerbated by the large proportion of items which are not acted upon by environmental forces and thus remain intact in the surrounding make solid waste a major issues in contemporary world (Huang, Q. F. et. al. 2006).

To curtail the production of these unwanted material, and disposing them away in ways that minimize the negative impacts of these material is termed as solid waste management (SWM) and it is the control of the generation, storage collection, transportation, treatment, utilization and disposal of the solid waste (Jain, A.P. and Pant, G.B. 1994). SWM can lead to resource recovery and conservation if implemented in its full essence (Huang, Q. F. et. al. 2006). It has been considered a basic urban service throughout the world and the efforts involved in managing waste have been a great hallmark of human endeavour for the betterment of the environment. The waste management psychology has been relying for a long time on simple solutions of throwing waste in water bodies, burning it as an alternative or burying it unconsciously as land filling (Chandrappa, R. \& Das, D. B. 2012).

Now with the inception of high-tech incineration technologies and concerted efforts in some parts of the world to drive communities towards zero waste societies, the world is just beginning to move towards making its urban centres more environment friendly (Dolgen D. 2005). An efficient SWM system needs organizational capacity and integrated cooperation between communities, private enterprises and municipal authorities, as it is responsible for the selection and adoption of appropriate technical and local solutions for waste collection, transfer, recycling and disposal (Gawaikar, V., Deshpande, V. P. 2006). The problems and solutions scenario changes as the globe moves from developed to developing world, where solid waste production and proliferation is a non-issue yet to be considered for its implications on society and environment (Centre for Sustainable Systems \& University of Michigan. 2012). Unfortunately, SWM has well-thought-out a neglected urban service in Pakistan (Gilgit-Baltistan Environmental Protection Agency, 2013). The federal and Gilgit-Baltistan governments have adopted a hands-off policy declaring it a local problem rather than a national one. As a result, the load on municipalities to manage solid waste is greater than their accessible meagre resources. Hence system failure starts, which is a matter of paramount importance (Henry, R. K., Yongsheng, Z., Jun, D., 2006).

Solid waste production is one of the dire environmental issues faced by the urban centres in Gilgit-Baltistan (GilgitBaltistan Environmental Protection Agency, 2013). The research scope encompasses study of waste production in commercial, residential areas, hospital, streets, link roads, municipal committee dumpsters, dustbins riversides and dumping sites and to find out the resourceful waste management techniques in Gilgit city. MCG is the organization responsible for SWM in town area. A diminutive proportion of the overall budget is earmarked for this imperative exertion (Gilgit-Baltistan Environmental Protection Agency, 2013). The objective of study was to identify and evaluate the generation of solid waste in Gilgit town in addition to give future consensus on the solid waste and detected the threats to natural scenic environment by solid waste.

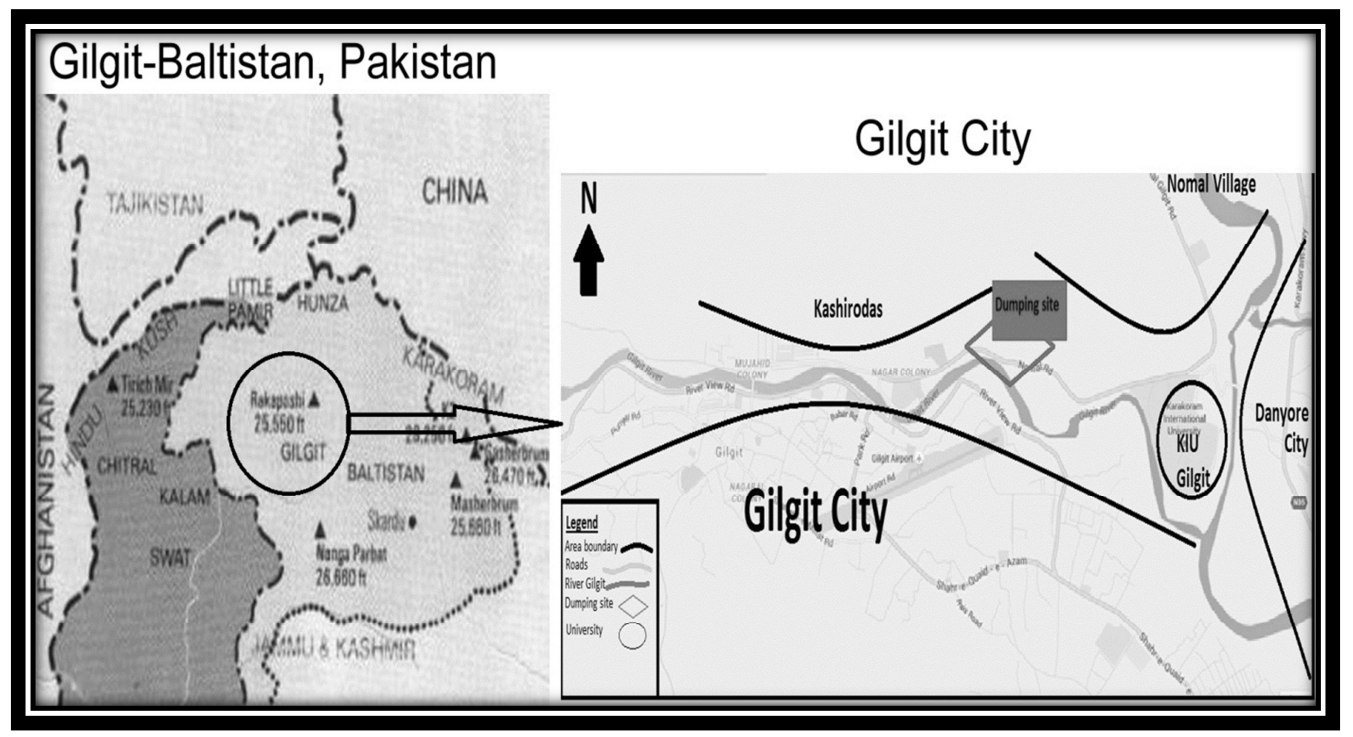

Figure 1. Map of the Gilgit City Waste Dumping Research Site. 


\section{Material and Methods}

\subsection{Study Area}

The study was carried out in administrative capital Gilgit of Gilgit-Baltistan situated at the confluence of Gilgit and Hunza Rivers. It is situated between 34-04 North latitude and 72-30 to 77-50 East longitudes. The city is longitudinally spread in a North-West to South direction along the Gilgit River. Town is 1490 meters above the sea level. Annually rain fall averages $165.4 \mathrm{~mm}$, min temperature $8.3^{\circ} \mathrm{c}$ and max temperature $23.6^{\circ} \mathrm{c}$ (M. Karrar \& Iqbal A., 2011).

\subsection{Research Design and Execution}

The research is based on questioners; interviews and observational study within the Gilgit town area. Primary data was collected including interviews with the concerned persons from the department of SWM such as the chief officer of MCG City. Scavengers and junk dealers were also interviewed to get an idea about what is scavenged as recyclables from the municipal waste. The secondary data on solid waste and its management aspects was also collected from the concerned department of the chief officer MCG. Field surveys on waste reclamation and its disposal practices were also carried out in different localities of the city. Special attention was given to the environmental hazards, associated with the solid wastes in low- income populations living close to the dumping site as shown in figure 1.

\section{Results and Discussion}

\subsection{MCG Organizational Structure and Resources}

MCG has the responsibility of SWM in Gilgit town and is working for collection; transportation and dumping of solid waste in town area two times a day on daily basis. Their places of dumping are Chlimishdas and Kashirodas. Following is the organizational structure of the organization.

Chairman $\rightarrow$ Chief Officer $\rightarrow$ staff $\rightarrow$ driver's $\rightarrow$ coolies' $\rightarrow$ sweepers

\subsection{Budget of MCG}

The present annual budget of MCG is Rs. 1,8900000 (USD 189, 000) annually for contingency expenditures. It also includes the machinery maintenance, other related expenditures with the solid waste transportation and pays of staff.

\subsection{Types of Waste in Waste Stream}

Polythene bags, Glass, Plastic bottles, Milk pack boxes, Poultry waste, Old tires, Cutting hairs, Old shoes, Clothes, Vegetables, Fruits, Mobile filters, Cold drink head, Glass bottles, Medicines, Cringes, Papers, Electricity items, Blades, Wood pieces, Others.

\subsection{Waste Handling Units of MCG}

The following five types of units are in use in the city:

1. Dustbins

2. Dumpsters

3. Dump containers

4. Metallic skips of 1 and $2.5 \mathrm{~m}^{3}$

5. Metallic containers $12 \mathrm{~m}$

\subsection{Waste at Source}

Normally, in some parts of the city, the refuse generated in the households as well as from the commercial areas partly is indiscriminately thrown on the roadsides. MCG recently installed $1 \mathrm{~m} 3$ capacity dustbins in the communities throughout the city that are occasionally used. This practice makes difficulties for the sweepers to collect, transfer and transport to the nearest collection points. However, the abovementioned practices obviously need some civic interventions to mend the people's psychology.

\subsection{Communal Storage on the Streets}

There are many dumping sites in the streets from where MCG transfer solid waste weekly (MCG 2007). MCG do not provide any dumpsters for streets. As a result of these crises, most of the refuse generated is openly dumped along the link roads and in open or vacant places providing ideal habitat for vermin.

\subsection{Equipments and Machinery Availability in MCG}

Details of equipments/machinery presently available with chief officer of MCG are given below in table.

Table 1. Equipments for solid waste collection and transport.

\begin{tabular}{llll}
\hline Equipment/Machinery & Total No. & In-order & Out of Order \\
\hline Tractor Trolleys & 4 & 4 & 00 \\
$\begin{array}{l}\text { Dustbins (installed) } \\
\begin{array}{l}\text { Dumpsters (containers } \\
\text { with wheels) }\end{array}\end{array}$ & 200 & 20 & 180 \\
Beats & 7 & 15 & 00 \\
Mazda & 1 & 7 & 00 \\
Hand wheel borrows & 25 & 1 & 00 \\
\hline
\end{tabular}

(Source MCG 2007)

\subsection{Waste Collection Methods of MCG}

The waste has to be picked up from the ground manually with the help of handcarts; baskets and in polythene bags. Irregular and uncontrolled sweeping, particularly in rush hours, creates problems for the general public. Average amount of sweeping collected in commercial areas is 10-12 $\mathrm{kg} /$ sweeper/day. In non-commercial areas, however, the average collection is $5 \mathrm{~kg} / \mathrm{sweeper} /$ day (admin officer MCG, 2004). With the equipment and machinery available with the MCG, maximum collection capacity of 15 tons/day can be 
achieved. The balance uncollected waste is 10 tons/day. This shows that there is a shortfall in lifting capacity of solid waste from jurisdiction of MCG. Only about $50-55 \%$ of solid waste is collected and transported to dumping site as shown in figure 1. The remaining waste is either burnt or remains on streets or in residential areas most of which is thrown in drains.

\subsection{Waste Transportation}

The vehicles and equipments available with MCG presently include 4 open body tractor trolleys and 1 Mazda truck are being used to collect and to dispose of the waste from different sites in the town area with the help of coolies allocated on each vehicle in numbers 2-3 (admin officer MCG, 2007).

These vehicles make 2-3 trips per working day. In congested areas of the city, handcarts are used for collection of waste to be emptied into tractors.

Table 2. Solid Waste Generation Gilgit City.

\begin{tabular}{ll}
\hline Parameters & Figures \\
\hline Current estimated population & 65845.6 \\
Domestic waste generated $0.16 \mathrm{~kg} / \mathrm{c} /$ day & $0.16 \mathrm{~kg} / \mathrm{c} / \mathrm{day}$ \\
Average solid waste per house hold & $1.38 \mathrm{~kg} / \mathrm{h} /$ day \\
Average solid waste non degradable from house hold & $0.275 \mathrm{~kg} / \mathrm{h} /$ day \\
Average solid waste degradable from house hold & $1.03 \mathrm{~kg} / \mathrm{h} /$ day \\
Hospital waste generated/day & $40 \mathrm{~kg} / \mathrm{day}$ \\
Total solid waste generated in Gilgit & 41 tons $/$ day \\
\hline
\end{tabular}

(Source: Personal observation and analysis July 2007)

\subsection{Dumping Sites}

The collected waste is dumped on roadsides and on barren land on various locations in the city vicinity. The largest dumping site (as shown in figure 1) is along the University road just outside the MCG jurisdiction situated at the right bank of Gilgit River, where water pollution due to sewage and solid waste cause severe water pollution.

\subsection{Solid Waste Generation in Gilgit}

The city of Gilgit generates a waste of about 40 tonnes per day, with a generation rate of $0.16 \mathrm{~kg} / \mathrm{capita} /$ day (personal observation and analysis). It produces a number of waste components, details of which are given in Table 2 .

\subsection{Problems with the Management of Solid Waste in Gilgit Town}

From the above discussion we conclude the following problems and issues that are being faced by MCG to manage solid wastes in Gilgit town;

- Absence of Waste Management Documentation.

- Spatial Disparities and Ineffective Resource Management.

- Disposal of waste without any environmental consideration.

- No operational maintenance and backup for waste collection and disposal equipment.

- Mixing of hazardous waste i.e. that generating from hospitals and laboratories with municipal waste.

- Unsafe operational conditions for working staff.

\subsection{Solid Waste from Commercial Units}

Survey revealed that the daily production of solid waste from commercial sector contributes 31.5 tonnes per day with an average of $3.15 \mathrm{Kg}$ per shop per day. Poultry shops are the highest contributors of waste producing $5.1 \mathrm{Kg}$ waste per day followed by Glass shops producing $3 \mathrm{Kg}$ per day and Baker's producing $2 \mathrm{Kg}$ per day on average. Average non-degradable waste generated from shops per day valued at $1.3 \mathrm{Kg}$ while degradable waste averaged 1.7 $\mathrm{Kg}$. Overall 12.9 tonnes of non-degradable waste is generated by commercial sector on daily basis together with 18.6 tonnes of degradable waste per day.

Table 3. Results of the commercial and household statistical data.

\begin{tabular}{|c|c|c|c|c|c|c|}
\hline Para meters & $\begin{array}{l}\text { Average solid } \\
\text { waste per/day }\end{array}$ & $\begin{array}{l}\text { Average solid waste } \\
\text { non degradable }\end{array}$ & $\begin{array}{l}\text { Type of Non - } \\
\text { degradable waste }\end{array}$ & $\begin{array}{l}\text { Types of } \\
\text { degradable waste }\end{array}$ & $\begin{array}{l}\text { Average solid } \\
\text { waste degradable }\end{array}$ & $\begin{array}{l}\text { Average solid waste } \\
\text { per shop/day }\end{array}$ \\
\hline $\begin{array}{l}\text { Solid waste } \\
\text { from/ bakery } \\
\mathrm{kg} / \text { day. }\end{array}$ & $2 \mathrm{~kg} /$ day & $1.4 \mathrm{~kg} / \mathrm{day}$ & $\begin{array}{l}\text { Bottles and heads } \\
\text { polythene bags, } \\
\text { juice boxes }\end{array}$ & $\begin{array}{l}\text { Papers and } \\
\text { bakery martial }\end{array}$ & $.6 \mathrm{~kg} /$ day & $3.15 \mathrm{~kg} /$ day \\
\hline $\begin{array}{l}\text { Solid waste } \\
\text { from/glass shop } \\
\mathrm{kg} / \text { day. }\end{array}$ & $3 \mathrm{~kg} /$ day & $2.5 \mathrm{~kg} / \mathrm{day}$ & Glass & Papers & $.5 \mathrm{~kg} /$ day & \\
\hline $\begin{array}{l}\text { Solid waste } \\
\text { from/ poultry } \\
\text { shop kg/day. }\end{array}$ & $5 \mathrm{~kg} /$ day & $0.1 \mathrm{~kg} /$ day & Polythene bags & Waste of poultry & $4.9 \mathrm{~kg} / \mathrm{day}$ & \\
\hline $\begin{array}{l}\text { Solid waste } \\
\text { from/ teashops } \\
\mathrm{kg} / \text { day. }\end{array}$ & $01 \mathrm{~kg} /$ day & $0.5 \mathrm{~kg} /$ day & $\begin{array}{l}\text { Milk pack boxes, } \\
\text { polythene bags. }\end{array}$ & $\begin{array}{l}\text { Waste of tea, } \\
\text { papers }\end{array}$ & $.5 /$ day & \\
\hline $\begin{array}{l}\text { Solid waste } \\
\text { from/ }\end{array}$ & $1 \mathrm{~kg} /$ day & $.3 \mathrm{~kg} / \mathrm{day}$ & $\begin{array}{l}\text { Tablets, polythene } \\
\text { bags, }\end{array}$ & $\begin{array}{l}\text { Papers, boxes of } \\
\text { tablets }\end{array}$ & $0.7 \mathrm{~kg} /$ day & \\
\hline Medical & & & Bottles & & & \\
\hline $\begin{array}{l}\text { Solid Waste } \\
\text { from } \\
\text { Greengrocer }\end{array}$ & $0.5 \mathrm{Kg} /$ day & $0.7 \mathrm{Kg} /$ day & Polythene bags & $\begin{array}{l}\text { Wooden crates, } \\
\text { fruit skins etc }\end{array}$ & $4.3 \mathrm{~kg} /$ day & \\
\hline
\end{tabular}


Table 4. Total commercial solid waste.

\begin{tabular}{ll}
\hline Parameters & Total solid waste/day \\
\hline $\begin{array}{l}\text { Average non degradable solid waste per } \\
\text { shop/kg/day }\end{array}$ & $1.3 \mathrm{~kg} / \mathrm{shop} / \mathrm{day}$ \\
$\begin{array}{l}\text { Average degradable solid waste per shop/kg/day } \\
\text { Total Non-degradable solid waste from } \\
\text { commercial area/day/tones } \\
\text { Total degradable solid waste from commercial } \\
\text { area/day/tones }\end{array}$ & $1.7 \mathrm{~kg} / \mathrm{shop} / \mathrm{day}$ \\
$\begin{array}{l}\text { Average solid waste per shop/kg/day } \\
\text { Total solid waste from commercial } \\
\text { area/day/tones }\end{array}$ & $3.15 \mathrm{~kg} / \mathrm{day}$ \\
\hline
\end{tabular}

\subsection{Solid Waste from Household}

From households in the city 11 tonnes of solid waste is generated per day. Each household produces about $1.38 \mathrm{Kg}$ wastes which mean $0.16 \mathrm{Kg}$ per capital per day of waste is generated. Out of total waste, 6.8 tonnes is degradable waste while 4.2 tonnes of non-degradable waste is generated. Thus non-degradable waste per capital figured as $0.033 \mathrm{Kg}$ per capital and $0.0974 \mathrm{Kg}$ as degradable waste per capital per day.

Table 5. Solid waste from household.

\begin{tabular}{lllll}
\hline Para meters & $\begin{array}{l}\text { Solid } \\
\text { waste/capita }\end{array}$ & $\begin{array}{l}\text { Average, non degradable solid waste } \\
\text { from per house hold kg/ day }\end{array}$ & $\begin{array}{l}\text { Average degradable solid waste from } \\
\text { house hold kg/day }\end{array}$ & $\begin{array}{l}\text { Average solid waste } / \text { house } \\
\text { hold kg/day }\end{array}$ \\
\hline $\begin{array}{l}\text { Solid waste from } \\
\text { house hold } / \text { day. }\end{array}$ & $0.16 \mathrm{~kg} / \mathrm{day}$ & $0.275 \mathrm{~kg} / \mathrm{day}$ & $1.03 \mathrm{~kg} / \mathrm{day}$ \\
\hline
\end{tabular}

Table 6. Total solid waste from household per day.

\begin{tabular}{ll}
\hline Parameters & Total/day \\
\hline Average non-degradable solid waste per capita & $0.033 \mathrm{~kg} / \mathrm{day}$ \\
Average degradable solid waste per capita & $0.0974 \mathrm{~kg} / \mathrm{day}$ \\
Total non degradable solid waste from & 4.2 tonnes/day \\
Total degradable solid waste from house hold & 6.8 tonnes/day \\
Total solid waste from household per day & 11 tonnes/day \\
\hline
\end{tabular}

Households contribute $26 \%$ i.e. 11 tonnes per day to the solid waste stream of the city remaining $74 \%$ i.e. 31.5 tonnes per day comes from commercial sector. The city generates 42.5 tonnes of solid waste daily.

Table 7. Total solid waste from Gilgit town area.

\begin{tabular}{ll}
\hline Parameters & Total/day \\
\hline $\begin{array}{l}\text { Total solid waste from commercial area Gilgit per } \\
\text { day/tonnes }\end{array}$ & 31.5 tonnes /day \\
$\begin{array}{l}\text { Total solid waste from house hold of town area per } \\
\text { day/tonnes }\end{array}$ & 11 tonnes /day \\
$\begin{array}{l}\text { Total solid waste from Gilgit town area per day in } \\
\text { tonnes }\end{array}$ & 42.5 tonnes/day \\
\hline
\end{tabular}

\section{Conclusion}

The present SWM is based on unplanned and haphazard service delivery mechanisms due to the absence of managerial and planning skills of concerned people in MCG. This is one of the important government departments that have no professional waste manager working in order to link various activities from generation to disposal through proper utilization of even available resources. The MCG lacks adequate data in order to provide facilities according to the needs of the town. The existing collection is without proper route designing. The elements of community participation are missing in the present SWM hierarchy of the department. The present transfer stations and disposal sites are not designed on scientific basis due to the lack of technical know-how of the associated officials. Open dumping of waste is equivalent to depositing the waste from one site to another only. The subsequent issues generated by the waste on spot equate the current waste management approaches just as squander of the resources. The environmental effects of the current disposal methods are detrimental to humans, flora fauna (of the area) and aquatic lives of river Indus. The dumping site (as shown in figure 1) is along river bed near at the Karakuram International University Gilgit which pollutes Gilgit River and create other nuisances such as burning release air pollutants, wandering feral dogs and other scavenger's population booms, aesthetic degradation of the city and foul smell etc.

\section{Acknowledgement}

Authors wish acknowledge all contributors who give their input during the research period and special thanks to local WWF-Pakistan, GCIC, NLI Colony, Jutiyal, Gilgit.

\section{References}

[1] Amber, I., Kulla, M.D., and Gukop, N. (2012). Municipal Waste in Nigeria Generation, Characteristics and Energy Potential of Solid, journal of Asian journal of engineering, sciences and technology, vol (2).

[2] Bai, R., \& Sutanto, M. (2002).The practice and challenges of solid waste management in Singapore. Journal of Waste Management, vol (22), pp 557-567.

[3] Chandrappa, R. \& Das, D. B. (2012).Waste Quantities and Characteristics. Solid Waste Management. Environmental Science and Engineering, DOI: 10.1007/978-3-642-286810_2.

[4] Bureau of Waste Prevention, Reuse and Recycling (2000). Characterization of New York City Waste Stream. Retrieved on September 10, 2015 from http://www.nyc.gov/html/nycwasteless/downloads/pdf/wpreports/wprr06.pdf. 
[5] Centre for Sustainable Systems \& University of Michigan (2012). Municipal Solid Waste Factsheet. Pub. No. CSS04-15. Retrieved on September 8, 2014 from http://css.snre.umich.edu/css_doc/CSS04-15.pdf.

[6] Dara, S.S. (1997). Environmental Chemistry and Pollution Control (chapter-4). New Delhi: S. Chand and Company ltd.

[7] Daskalopoulos, E., Badr, O., Propert, D. S. (1998). 'Municipal Solid Waste: A Prediction Methodology for the Generation Rate and Composition in the European Union Countries and United States of America, Resources Conservation and Recycling'. vol (24), pp 155-166.

[8] Dolgen, D., Sarptas, H., Alpaslan, N., \& Kucukgul, O. (2005).Energy potential of municipal solid wastes. Journal of Energy Sources, vol (15), pp 1483-1492.

[9] Gilgit-Baltistan Environmental Protection Agency (2013).Quantities and Characteristics of Solid Waste in Seven Urban Centres of Gilgit-Baltistan. Gilgit, Pakistan.

[10] Ejaro, S. P., \& Jiya, S. N. (2013). Source Specific Quantification, Characterisation and Management of Solid Waste in Lapai, Niger State, Nigeria. Ethiopian Journal of Environmental Studies and Management, Vol. 6 No.5 2013. Retrieved on September 5, 2013 from http://dx.doi.org/10.4314/ejesm.v6i5.14.
[11] Gawaikar, V., Deshpande, V. P. (2006). Source Specific Quantification and Characterization of Municipal Solid Waste a Review.

[12] Guangyu, Y. (n. d.). (2014). Amount and Composition of Municipal Solid Wastes. Point Sources of Pollution: Local Effects and its Control, Vol. 1. c09/E4-11-03-02.

[13] Henry, R. K., Yongsheng, Z., Jun, D. (2006). Municipal solid waste management challenges in developing countries Kenyan case study. Waste Management, vol 26(1), pp 92-100.

[14] Huang, Q. F., Wang, Q., Dong, L., Xi, B. D., Zhou, B. Y. (2006). The current situation solid waste management in China. J. Mater. Cycle Waste Manag. 8.

[15] International Resource Group, Ltd. (2009). Solid Waste: Generation, Handling, Treatment and Disposal (chapter: 15). Retrieved on September 10, 2014 from http://www.encapafrica.org/.

[16] Jain, A.P. and Pant, G.B. (1994). 'Solid Waste Management in India,' paper presented at the 20th WEDC Conference, Colombo, Sri Lanka.

[17] Karrar M. \& Iqbal A. (2011). Gilgit City Report. NED University of Technology, Karachi, Pakistan. 